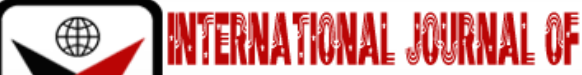

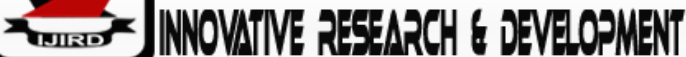

ISSN 2278 - 0211 (Online)

\section{The Effect of Nutrition Education Using Booklets on Body Mass Index in Obese Adolescent: Literature Review}

Rosi Rose
Alumni, Polytechnic Health Ministry of Health, Republic of Indonesia Bengkulu, Indonesia
Meriwati Mahyuddin
Lecturer, Polytechnic Health Ministry of Health, Republic of Indonesia Bengkulu, Indonesia
Arie Krisnasary
Lecturer, Polytechnic Health Ministry of Health, Republic of Indonesia Bengkulu, Indonesia

\begin{abstract}
:
Background Obesity is a condition that does not balance incoming energy with the needs of a person's body. Being overweight in adolescence is a risk factor for chronic diseases and will be associated with an increased risk of obesity in adulthood. Factors that influence obesity were the interaction between genetic factors, family environmental factors and diet. In addition, there are other factors that cause obesity, including metabolic, genetic, nutritional, socioeconomic, cultural, psychological, and lifestyle factors. The Objective of this study was to analyzed the effect of balanced nutrition education through booklets on body mass index in obese adolescents. Method. This research was a descriptive study, also called the interpretive method because the research data was more concerned with the interpretation of the data found. Literature study technique was used in this research to found relevant and supportive sources. Result. Based on 4 articles on the influence of nutritional education on body mass index in obese adolescents, it was found that educational media in the form of booklets affect the body mass index of obese adolescents while other media in the form of video media and social media Instagram does not affect.

in obese adolescents.
\end{abstract}

Keywords: Adolescents, obesity, body mass index, nutrition education

\section{Introduction}

Adolescence is one of the important and decisive periods of growth and development in the next period of development. Adolescents who are obese, later in adulthood tend to be obese. It has been proven that the incidence of obesity in the transition period between adolescents and young adults within five years increased, namely $10.9 \%$ to $22.1 \%$ and $4.3 \%$ of them had a BMI of 40 .

Nutrition is better known as obesity has a problem that occurs because the imbalance between the amount of energy consumed is too large than the amount of energy expended. Obesity in adolescents has problems that will have an impact on declining health and productivity. Obesity is a condition that is not balanced between the energy that enters and the needs of a person's body. Obesity is caused by several factors. Lack of physical activity is a major risk factor for the incidence of obesity.

Being overweight in adolescence is a chronic causative risk factor that will be associated with an increased risk of obesity as an adult. Things that can happen due to being overweight are increasing risk factors for metabolic syndrome which is a person's clinical condition that causes metabolic disorders including obesity, abnormalities in blood fat levels, especially cholesterol, and increased blood pressure.

Prevalence according to the World Health Organization (WHO) that by 2020, more than 2.8 million people die each year from being overweight or obese, and an estimated 35.8 million (2.3\%) of Disability-adjusted life year (DALY) or the global number of deaths are caused by overweight or obesity.

The results of basic health research (RISKESDAS) in 2013 and 2018, the prevalence of obesity of adolescents aged $\geq 15$ years in Indonesia increased from $26.6 \%$ to $31 \%$. Riskesdas results of Bengkulu Province in 2018, the prevalence of adolescent obesity aged $\geq 15$ years is $30 \%$ (Riskesdas, 2018). The results of Riskesdas Kota Bengkulu in 2018, the prevalence of adolescent obesity aged $\geq 15$ years amounted to 5,513 people or $64.9 \%$. Meanwhile, the most data affected by obesity is in the Bengkulu City Fish Market which amounted to 2,972 people or 28.85\%.

Parameters are often used to determine an obese person using BMI. BMI is a type of nutritional gauge used to measure weight and find out if our body is classified as thin, ideal, normal, or fat.

Nutrition education can be provided through various media that are divided into three types, namely audio media, visual media, and audio-visual media. Nutrition education can be provided through a booklet that includes types of visual 
media. Booklet is a medium that can convey health messages in the form of books with a combination of writing and images that have the advantage of information that is poured more complete, more detailed, clear and educative.

Based on the results of research L. Putri et al., 2020 shows that there is an influence on increased knowledge in the prevention of overweight and childhood obesity. According to research shows that there is a significant increase before and after nutritional counseling balanced with more effective booklet media. And according to the results of research Dyah Ayu Saputri (2017) shows that there is a balanced nutritional extension influence on adolescent motivation in obesity prevention after being given balanced nutritional counseling.

Based on the background of the researchers, researchers are interested in reviewing the influence of balanced nutrition education through booklets on body mass index in obese adolescents.

\section{Method}

Based on the purpose of research design this research was categorized as descriptive research, because the approach taken was qualitative approached. This method is also called interpretive method because the data results of research are more concerned with interpretation of the data found.

The research technique used in thesis writing is the study of literature by researching and understanding relevant sources and supporting the influence of balanced nutrition education through booklets on body mass index in obese adolescents. Sources of literature included journals or articles.

The research design taken in this scientific search was experimental and case-control studies. The main intervention examined in this scientific search is the influence of balanced nutrition education through booklets on body mass index in obese adolescents. The outcome measured in this scientific search was the influence of balanced nutrition education through booklets on body mass index in obese adolescents. Search for published articles on PubMed, google scholar, proquest with selected keywords namely obese adolescents, body mass index, balanced nutrition education, booklet. Articles or journals that fitted the criteria of inclusion and exclusion were taken for further analysis. This literature review used literature published 2016-2021 which can be accessed fulltextinportable document format (pdf) and scholarly (peer reviewed journals) format. The criteria of the journal reviewed were Indonesian and English research journal articles with adolescent subjects, types of journals of non-literature review research articles with the theme of the influence of balanced nutrition education through a booklet on body mass index in obese adolescents. Journals that were in accordance with the criteria of inclusion and there is a theme of the influence of balanced nutrition education through booklets on body mass index in obese adolescents. From the point of view of obese adolescents, nutritional education is balanced, then a review was carried out. The criteria of the journal selected for review was a journal in with an influence of balanced nutrition education through booklets on body mass index in adolescents.

\section{Result}

\subsection{Characteristics of Research}

\begin{tabular}{|c|c|c|c|c|}
\hline No. & $\begin{array}{l}\text { Author, Year, Country, } \\
\text { Research Design }\end{array}$ & $\begin{array}{l}\text { Target/Aged/ } \\
\text { Frequency of } \\
\text { Interventions }\end{array}$ & Purpose of Intervention & Media \\
\hline 1 & $\begin{array}{c}\text { Fithra, 2021, Indonesia, } \\
\text { Quasy-experimental }\end{array}$ & $\begin{array}{l}\text { Obese Teenager } \\
(19-22 \text { years }) \\
30 \text { days }\end{array}$ & $\begin{array}{c}\text { Found out the influence of nutrition } \\
\text { education and motivational classes on } \\
\text { healthy weight loss practices in obese WUS }\end{array}$ & $\begin{array}{l}\text { Social } \\
\text { media }\end{array}$ \\
\hline 2 & $\begin{array}{l}\text { Normayanti, } 2020 \text {, } \\
\text { Indonesia, Quasy- } \\
\text { experimental }\end{array}$ & $\begin{array}{l}\text { Obese Teenager } \\
\text { (14 - } 17 \text { years }) \\
3 \text { months }\end{array}$ & $\begin{array}{c}\text { Determined the effect of nutrition education } \\
\text { through the DASH diet booklet on body mass } \\
\text { index (BMI), waist circumference, upper arm } \\
\text { circumference (LILA), and blood pressure in } \\
\text { obese adolescents at State High School } \\
\text { Surakarta. }\end{array}$ & Booklet \\
\hline 3 & $\begin{array}{c}\text { Irfan, 2020, Indonesia, } \\
\text { Quasy-experimental }\end{array}$ & $\begin{array}{l}\text { Obese Teenager } \\
(13 \text { - } 14 \text { years }) \\
7 \text { months }\end{array}$ & $\begin{array}{l}\text { Determined the effect of nutrition education } \\
\text { with booklet media on fast food } \\
\text { consumption patterns, calorie intake and } \\
\text { changes in body weight (BMI) in adolescents } \\
\text { at Medan Junior High School, North } \\
\text { Sumatera }\end{array}$ & Booklet \\
\hline 4 & $\begin{array}{l}\text { Meylinda, 2019, } \\
\text { Indonesia, Quasy- } \\
\text { experimental }\end{array}$ & $\begin{array}{l}\text { Obese Teenager } \\
(17-22 \text { years }) \\
24 \text { days }\end{array}$ & $\begin{array}{l}\text { Found out knowledge and attitudes about } \\
\text { body image through video on } \\
\text { anthropometric assessment (BMI, WHR) in } \\
\text { obese students at Polytechnic of the Ministry } \\
\text { of Health Kemenkes Yogyakarta }\end{array}$ & Video \\
\hline
\end{tabular}

Table 1: Results Summary of Characteristics in Obese Adolescents 


\subsection{Body Mass Index}

\begin{tabular}{|c|c|c|c|c|c|c|c|c|c|}
\hline & \multicolumn{3}{|c|}{ Intervention } & \multicolumn{3}{c|}{ Control } & \multicolumn{3}{c|}{ P value } \\
\cline { 2 - 9 } No & Before & After & Change & Before & After & Change & Before & After & Change \\
\hline 1. & 29.5 & & 0.07 & 28.3 & & 0.1 & 0.279 & 0.482 & $>0.05$ \\
\hline 2. & 30.68 & 30.31 & 0.36 & 30.5 & & 0.29 & $<0.001$ & $<0.001$ & $<0.001$ \\
\hline 3. & & & & 26.8 & & & & & $<0.001$ \\
\hline 4. & & & & 30.3 & & & & & $>0.05$ \\
\hline
\end{tabular}

Table 2: Summary of Nutrition and Media Education Interventions on BMI in Obese Adolescents Source: Research Data, 2021

Based on Table 2, articles that have been selected and collected into one document according to the criteria of inclusion from various database sources, two of the four articles showed the influence of nutrition education after being educated using visual media in the form of booklets.

\section{Discussion}

\subsection{Characteristic}

Research conducted by Dieny, et al (2021), there were age characteristics ranging from 19-22 years were active students of Diponegoro University, given nutritional education in the form of information about nutrition using instagram social media with a 30-day intervention period.

Research conducted by Normayanti, et al (2020), there were characteristics of age ranging from 14-17 years teenagers in Surakarta State High School, being educated in the form of dietary diet Dietary Approaches to Stop Hypertension (DASH) using media booklet with a 3-month intervention period.

Research conducted by Said, et al (2020), there were ages ranging from 13-14 years to adolescents in Junior High School in Medan, provided nutritional education interventions on fast food consumption patterns, calorie intake, and changes in body mass index (BMI) with media booklet on body mass index with an intervention length of 7 months.

Research conducted by Nurun (2019), there were age characteristics starting from 17-22 years, students of The Yogyakarta Ministry of Health, provided nutritional education about body image through video with a 24-day intervention period.

\subsection{Effect of Nutrition Education on Body Mass Index in Obese Adolescents}

The study was conducted by Dieny, et al (2021), before the intervention with p value was 0.279 and after the intervention was 0.482 . It was concluded that Instagram social media education was no difference with $p$ value $>0.05$ or the absence of changes in body mass index by being given nutritional education. This is due to the lack of time to provided nutrition education through social media conducted for 30 days in the form of pictorial nutrition information equipped with a simple explanation in the form of understanding material about obesity, how to measure obesity, and recommended food intake for obesity.

Research conducted by Normayanti, et al (2020), before the intervention p value was <0001, after the intervention $\mathrm{p}$ value was $<0001$. After the intervention, significant changes were made. Nutrition education through booklets in research can help adolescents to be able to change excessive daily energy intake to be more balanced as needed gradually. This was because of the frequent giving of booklet contents to teenagers who are equipped with an explanation of the contents of the booklet. It was concluded that the provision of booklet media education has an effect on the decrease in body mass index (BMI) or changes in adolescent body mass index.

The study conducted by Said, et al (2020), can be seen from before the intervention p value was $<001$ and after the intervention $\mathrm{p}$ value was $<0001$. This was because of the frequent provision and explanation of nutritional education through a booklet raised new knowledge and further responses in the form of actions that make adolescents motivated to lose weight that affect calorie intake and changes in body mass index (BMI). It can be concluded that the nutrition education of the booklet media had an effect on the decline of adolescent BMI.

The study conducted by Nurun, can be seen from before and after the intervention showed $p$ value was $>0.05$. There was an insignificant increase in body mass index between before and after being educated via video. This was because the lack of time to provide nutritional education about body image through video has no effect on the decrease in body mass index (BMI) due to lack of knowledge and does not change its behavior related to eating consumption and physical activity.

Providing nutritional education to adolescents can be a preventive measure for the occurrence of obesity, as it is known in previous studies that nutritional knowledge in most obese adolescents allows less to choose a nutritious diet and can eventually affect the body mass index (BMI) incidence of obesity in adolescents. Educational media is a tool used to facilitate the delivery of information. The visual medium used in the four articles analyzed was the booklet. Meanwhile, for audio visual media used are video and social media.

The use of visual media can help researchers in delivering influential education to use. Some people have different learning styles. According to Bobby De Poter and Mike Hernacki (Deporter, 2000) explained in general human learning styles are divided into three large groups, namely: 1) visual learning styles (seeing, observing, and looking); 2) auditorial learning style (listening); 3) Kinesthetic learning style (moving, working, and touching). 
The duration time span used during the intervention process varied significantly from 30 days, from 3 months, 7 months, and 24 days. There is one article with an intervention time of 30 days. There is one article with a 3-month intervention length. There is one article with a 7-month intervention length. There is one article with a 24-day intervention length. Three of the four articles reviewed conducted a direct study targeting school teenagers.

There were two of four articles that state a significant change in body mass index after being given nutritional education using the help of a media booklet. One in four articles said there was no significant change in body mass index after being given nutritional education using the help of social media Instagram. One in four articles said there was no significant change in body mass index after being given nutritional education using the help of video media.

\section{Conclusion}

Characteristics of age in article 1 from the age of 19-22 years, article 2 from ages 14-17, article 3 from ages 13-14. Article 4 from ages 17-22.0verview of BMI prior to intervention in article 1 of the treatment group 29.5 and control 28.3. Article 2 described BMI treatment group 30.68 and control 30.54. Article 3 of the treatment group did not contain an image of BMI and a picture of IMT control group 26.81. Article 4 of the treatment group does not contain an image of BMI and a bmi picture of the control group 30.3. The picture of BMI after intervention in article 1 of the treatment and control group does not contain a bmi image. Article 2 of the treatment group contains an overview of BMI 30.31 and control 30.83 . Article 3 of the treatment group does not contain an IMT image and there is a control BMI image of 26.58 . Article 4 of the treatment group does not contain an image of IMT and there is a picture of IMT control 30.32. Based on 4 articles the influence of nutritional education on body mass index in obese adolescents in the article in the form of a media booklet affecting body mass index in obese adolescents is found in 2 articles and 2 articles on the influence of nutrition education that does not affect BMI proves that nutrition education in the form of video media and social media in the form of Instagram had no effect on body mass index in obese adolescents.

\section{Suggestion}

Furthermore, literature review research can use the Diagram Preferred Reporting Item for Systematic Review and Meta-Analysis (PRISMA) as a research process in selecting or searching for articles to be reviewed. For educational institutions, who want to provide education about obesity in adolescents is advised to use visual media in the form of booklets as a tool that facilitates the teaching and learning process.

\section{References}

i. Adik Wibowodan Vetty Yulianty Permanasari. (2020). Practical Guidelines for Compiling Thesis and Scientific Manuscript Using Literature Review. Department of AKK FKM University of Indonesia.

ii. AndiSaifah, D. (2019) 'Peer Education on Nutrition Practices and Body Mass Index of School-Age Children Who Experience More Nutrition'. Healthy Tadulako Journal (JurnalKesehatanTadulako), 5 (3).

iii. Arsyad, A. (2006) Learning Media. Jakarta: PT Raja Grafindo

iv. Assidhiq, M. R. (2019) The Influence of Nutrition Education With E-Booklet Media on Knowledge, Attitudes, Eating Behaviors and Weight Loss About Obesity Prevention Efforts in Adolescents in SmaNegeri 9Semarang. Department of Nutrition. PoltekkesKemenkes Semarang. Skripsi.

v. CDC. (2016). Centers of Disease Control and Prevention. Available at: https://www.edc.gov/obesity/childhood/causes.html.

vi. Christianto, D. A. et al. (2018) 'Relationshipof Physical Activity To Obesity Incidence Based on Body Mass Index In BanjaroyoKulonProgo Village of Yogyakarta Special Region',Periodic Scientific Medicine Ambassadordiscourse, 3(2), pp. 78-88.

vii. Dewi, R. C., Oktiawati, A. and Saputri, L. D. (2015) 'Theory \& Concept of Baby Growth, Toddler, Child and Adolescent Age', Yogyakarta: PT. NuhaMedika.

viii. Diba, N. F., Pudjirahaju, A. and Komalyna, I. N. T. (2020) 'The Influence of Balanced Nutrition Extension with Media Booklet On Knowledge, Attitudes, Diet, Physical Activity and Weight overweight adolescents SMPN 1 Malang', JurnalNutriture, 1(1), pp. 33-52.

ix. Dinkes Kota Bengkulu. (2017). Health profile of bengkulu city : Bengkulu

x. FifiantyasAmalia, D. (2018) 'The Influence of Nutrition Education on The Knowledge and Practices of Prospective Mothers In The Prevention of Chronic Energy Of Pregnant Women (Study on Newlyweds In The Working Area of Duren Health Center, Bandungan,Semarang)'. Journal of Public Health (e-Journal), 6(5), pp. 370-377.

xi. Gemilang, R. (2016) 'Booklet Development as An Information Service Medium For Understanding The Lifestyle of Hedonism Of Class Xi Students In Sman 3 Sidoarjo the Development of Booklet As an Information Service Media To Understand Hedonism Life Style of Eleventh Grade Students in Sman 3 S', Jurnal BK Unesa, 6, pp. 3-9.

xii. H.R Hasdianah, Sandu, S, N. (2017) PemanfaatGizi, Diet, danObesitas. Yogyakarta: PT. Nusa Medika.

xiii. Hapsari, C. M. (2013) 'EfektivitasKomunikasi Media Booklet 'AnakAlami’ Sebagai Media PenyampaiPesan Gentle Birthing Service', Jurnal e-Komunikasi. Available at: https://www.mendeley.com/catalogue/cf815eff62f4-39ec-9ff5-e1ee4097384e/.

xiv. Khasanah. (2012). Beware of Various Degenerative Diseases Due to Diet. First print. Yogyakarta: PT. Publisher Like.

xv. KementrianKesehatan RI (2014) 'PGS Health Guidelines', Balanced Nutrition Guidelines, pp. 1-99. 
xvi. Marfuah, D. and Kurniawati, I. (2017) 'Efforts to Increase Maternal Knowledge about Breast Milk MP with Nutrition Education Through Booklet', The 6th University Research Colloquium, pp. 273-280. Available at: http://journal.ummgl.ac.id/index.php/urecol/article/view/1195.

xvii. Notoatmodjo, S. (2012) Health Research Methods (Revision2). Jakarta: PT. RinekaCipta.

xviii. Novita Sari, F. and Widyatuti (2020) 'Gender, Physical Exercise and Obesity in School-AgeChildren', 12(1). Thesis.

xix. ProverawatidanKusumawati. (2011). Nutrition Science for Nursing and Health Nutrition.Yogyakarta: PT. NuhaMedika

xx. Putri, L. Lely, L. Fitri, H. (2020) 'The Influence of Education Using Booklets on Parents' Knowledge in Caring for Overweight and Obese Children In Public Elementary School Depok Ii Health Center Working Area of Sleman YogyakartaRegency', Journal of Health Sciences, 10(1), pp. 1693-6868. Available at: http://ejournal.urindo.ac.id/index.php/kesehatan.

xxi. Rahmy, H. A. (2020) 'Nutritional Education Guidelines for Balanced Nutrition And Contents of My Plate In Children of State Elementary School 06 BatangAnai Padang Pariaman Regency. Nagari Scientific Bulletin Building Website. http://buletinnagari.lppm.unand.ac.id E-ISSN:, 3(2), pp. 162-172.

xxii. RendyAjiPrihaningtyas, dkk. (2018). Childhood Obesity Impacts on Health and Development. PT. Elex Media Komputindo. Jakarta.

xxiii. Riskesdas, K. (2018) 'Key Results of Basic Health Research (RISKESDAS)', Journal of Physics A: Mathematical and Theoretical, 44(8), pp. 1-200. doi: 10.1088/1751-8113/44/8/085201.

xxiv. Safitri, N. R. D. (2016) The Influence of Nutrition Education with Lectures and Booklets on Improving The Knowledge and Attitude of Overweight Adolescent Nutrition. Semarang: Diponegoro University. Research articles.

xxv. Saputri, D. A. (2017). The Influence of Balanced Nutrition Extension on Motivation to Prevent Obesity in Class XI Students at Muhammadiyah High School 7 Yogyakarta.Thesis.

xxvi. Sukardi. (2004). Methodology of Educational Research: Kopetensi and Its Practices.Jakarta: PT. Earth Script.

xxvii. Suparyatmo, J.B. and Prayitno, A. (2020)'The Effect of Nutrition Education on Body Mass Index, Waist Circumference, Upper Middle Arm Circumference and Blood Pressurein', Journal of General Medicine Electronics, 17(5).

xxviii. Suiraoka, I. (2016). Degenerative diseases. Yogyakarta: PT. NuhaMedika. Recognize, Prevent and Reduce Risk Factors 9 DegenarativeDiseases, Degenerative Diseases,41-54.

xxix. SyamsiarWulandari, D. (2016)'Factors Associated with The Incidence of Obesity in Adolescents in State High School 4 Kendari',Scientific Journal of Health Students, 1(3).

xxx. Talib, S. (2010) Educational Psychology Based on Applicative Empirical Analysts. Yogyakarta: PT. Kencana Media Group.

xxxi. Widyastuti, Y., Rahmawati, A., Purwaningrum, Y. (2009) Reproductive Health. Yogyakarta: PT. Fitramaya. 